\title{
DISCURSO DE AGRADECIMENTO
}

José Henrique Santos

Recebo, entre surpreso e agradecido, a homenagem que me prestam amigos e colegas com a publicação desta coletânea de textos sobre Ética, Política e Cultura. Os assuntos aí tratados nos aproximaram no convívio acadêmico e mesmo fora dele, mas, como era de se esperar entre filósofos, também nos dividiram, com muito respeito, quanto às convicções e atitudes. Honra-me, sobretudo, ter sido pretexto para que se escrevessem tantos textos significativos sobre temas que me ocuparam na vida de professor, e para os quais procurei contribuir, modestamente, na medida de minhas forças. O consenso sobre minha pessoa, expresso na homenagem, provém, sem dúvida, da generosidade dos amigos; bem sei, no entanto, que tal concordância só pode fazer-se na forma da controvérsia, própria do discurso filosófico e da dificuldade das questões com que todos nos defrontamos. Elas dizem respeito à totalidade da vida e da morte, da natureza e da liberdade, em breve, das múltiplas manifestações do ser. Aristóteles já nos havia advertido que o ser se diz de muitas maneiras. A crítica não é apanágio de inimigos, constitui, antes, um dos deveres da amizade.

Nesta coletânea de colegas não falta até mesmo o "fogo amigo", como dizem hoje os jornais que noticiaram a última guerra, mas que, tomado à letra, para os iniciados nos misteres filosóficos, está mais a arder no fogão de Heráclito, junto ao qual se aquecia o filósofo, pois "aqui também habitam os deuses", como disse aos curiosos que buscavam vê-lo; aproximai-vos, portanto. Não devemos, dizia ele, rezar pela paz, pois nos arriscaríamos a aniquilar tudo o que existe, tanto é verdade que "o conflito é pai de todas as coisas". Guerra ou conflito se diz em grego pólemos, donde deriva nossa polêmica, sem a qual, de fato, o pensamento criador não poderia subsistir sem perder-se na banalidade. Todos os que lemos a biografia de Heidegger escrita por Safranski sabemos que foi com este argumento que o filósofo se 
defendeu perante os que o acusaram de ter feito a apologia da guerra que culminou no holocausto dos fornos crematórios.

Peço desculpas por passar tão de repente, sem a conveniente preparação, a este ponto extremo da história de nossa época. Na verdade, a maldade do mundo parece não ter limites, mas é nosso dever inquirir suas causas e denunciá-las com coragem; pois só assim, creio eu, a verdade nos libertará. A teoria filosófica, qualquer que seja, deve completar-se com a ortopraxia, isto é, com a ética exemplar de nossa vida. Estou certo de que, neste particular, estamos todos juntos e de acordo. Quanto às nossas teorias e crenças, vale, sem contestação, o dito atribuído ao Estagirita: sou amigo dele, mas mais amigo da verdade. Mas o mesmo Platão, alvo do comentário, no Sofista, 242d, também se viu compelido a tomar posição entre os partidários do uno e do múltiplo, e o fez com infinita graça, dizendo que "devemos proceder como as crianças, que querem os dois ao mesmo tempo".

Um partidário do múltiplo considerou-me panglossiano ao avesso, descrente das benesses deste mundo e de todo o progresso, tal o meu pessimismo. Direi que não; - mas deveria mesmo dizer que vivemos no melhor dos mundos possíveis, como Candide, o crédulo discípulo do mestre que sabia todas as línguas e justificava todas as coisas? Porque, na verdade, o curso do mundo parece estar cada vez pior, ao menos para a imensa maioria dos deserdados e excluídos. Caberia argumentar, candidamente, que, se as coisas ainda podem piorar, é que ainda são suficientemente boas, do contrário não poderiam mais corromper-se? Diríamos, portanto, como bons otimistas, das guerras e das pestes que assolam outras partes do mundo, que poderiam ser piores do que realmente o são? Pelo menos ainda não nos atingiram. Por quanto tempo? Já não nos bastam nossos próprios males, injustiças sociais, violência, corrupção dos costumes? Permito-me buscar a companhia de um santo da Igreja, para não me sentir perdido e encontrar algum consolo. Disse ele em suas Confissões:

"Vi claramente que todas as coisas que se corrompem são boas: — não se pode-
riam corromper se fossem supremamente boas, nem se poderiam corromper se
não fossem boas. Com efeito, se fossem absolutamente boas, seriam incorruptí-
veis, e se não tivessem nenhum bem, nada haveria nelas que se corrompesse"
(Conf., VII, 12).

Uma distinção importante precisa ser feita, porém, para que a tese não perca seu exato sentido metafísico. Ela supõe que Deus, e só Ele, é a Verdade e o Bem supremos, e que todas as coisas criadas, sendo apenas relativas, não podem ser tomadas como a medida de si mesmas. Esta dialética do bem coloca seu autor entre os partidários do Uno, Princípio e Fim de todas as coisas, 
porque o mal consiste, precisamente, em considerar a parte como se fosse uma substância independente do todo, o que ela não é. O fato em si nada significa se não for habitado por algo — um sentido — que o transcende absolutamente. Mesmo o fato histórico carrega no adjetivo "histórico" o sentido que o torna universal, e, portanto, paradigmático para medir a verdade de uma época, vem a ser, sua própria historicidade. Fugindo às armadilhas do historicismo, direi que o Sentido é transcendência, e a história pensada no conceito salva o fato de sua caducidade. Também Agostinho proclamou, a seu modo, que "só o todo é verdadeiro", pois não confessou ao Senhor seu Deus que "nosso coração está inquieto até que repouse em Tî"?

A sátira de Voltaire continua atual, mesmo no mundo do progresso, da ciência e da técnica, sem os quais não mais poderíamos viver. É provável que Pangloss não conhecesse a dialética das Confissões, pois a teria incorporado à sua erudição - seria também ela melancólica pelo fato de não se contentar com uma satisfação limitada?

Com todo seu furor e ruído, o mundo moderno não escapa da vulgaridade; acentuaram-no em análises notáveis, Ortega, em A Rebelião das Massas, e Heidegger, ao descrever o das Man em Ser e Tempo. Mas foi James Joyce quem descreveu com mais vigor a infinita banalidade da cidade moderna, ao fotografar (é bem o termo) um único dia na vida de Dublin, numa espécie de réplica urbana da Odisséia. Ao novo Ulysses não escapou a dialética negati$v a$ de Agostinho que, inserida no novo contexto, ao qual falta a transcendência, provoca um mal-estar próximo da mais absoluta derrelição. Por que se inverte, ou melhor, se perverte o sentido da tese? Justamente: porque, arrancada do solo metafísico, ela se torna uma contradição por insuficiência, na feliz expressão de um querido amigo. Sem poder reproduzir o contexto em que Joyce a coloca, cito porém a frase no original e faço o melhor que posso para traduzi-la:

"It was revealed to me that those things are good which yet are corrupted which neither if they were supremely good nor unless they were good could be corrupted". ("Foi-me revelado que são boas aquelas coisas que apesar de estar corrompidas, não sendo supremamente boas, ou sendo ao menos boas, podiam ser corrompidas"). $\mathrm{O}$ original não traz qualquer pontuação.

Como bem disse recentemente Edgar Morin, vivemos numa época na qual o possível se tornou impossível. Este é o paradoxo (ou será uma contradição?) que temos de reverter. Pois, afinal, a rosa da razão só floresce no chão da cultura. Ou estará nossa civilização fadada à barbárie? Pode uma grande cultura, que já dessacralizou a tradição religiosa que a viu nascer, subsistir sem metafísica? Deixar-nos-emos seduzir pelo gozo da técnica e do 
mundo administrado, sem inquirir seu fundamento e essência? Nossa responsabilidade é tanto maior quando consideramos que, no mundo da informação instantânea e da Internet, o trabalho intelectual se tornou uma forma de agir. As discussões acadêmicas podem aspirar ao teatro do mundo.

Toda época tem sua pretensão de modernidade; se algumas são dignas de rememoração, como no período clássico grego, ou a culminância da cristandade medieval no século XIII, elas o são, não devido aos fatos em si peremptos, mas à cultura simbólica que tal modernidade foi capaz de criar a partir desses mesmos fatos. A significação profunda de nossa modernidade reside, sobretudo, embora não exclusivamente, nos desafios que o progresso científico e tecnológico nos coloca, a exigir soluções práticas, sem dúvida, mas não menos humanas, ou, mais exatamente, espirituais. Está em questão o próprio homem.

Só me falta agora agradecer a todos os colegas e amigos que tão carinhosamente me prestaram esta significativa homenagem. Os textos estão magníficos e por certo terei muito o que aprender com eles. Agradeço, de modo especial a Ivan Domingues, Paulo Roberto Margutti Pinto e Rodrigo Duarte, organizadores da coletânea e autores de uma apresentação brilhante e generosa de meus escritos, que soube preservar a unidade de pensamento que escapa ao leitor dos textos isolados. Preciso mencionar também a impecável revisão do Prof. Hennio Morgan Birchal, a quem rendo minhas homenagens. Agradeço, por fim, à Universidade Federal de Minas Gerais, representada por sua Magnífica Reitora, Ana Lúcia Almeida Gazzola, à Faculdade de Filosofia e Ciências Humanas, representada por seu Diretor, Prof. João Pinto Furtado, ao Departamento de Filosofia, na pessoa de seu Chefe, meu colega Leonardo Alves Vieira. Também rendo meu tributo à Editora da UFMG e a seu Conselho Editorial, presidido pelo Prof. Wander Melo Miranda, responsáveis pela cuidadosa edição da coletânea, que nos apresenta, além disso, uma capa de grande beleza. O mesmo agradecimento é extensivo aos oradores que me saudaram, com os exageros que a amizade explica, bem como a todos os presentes a esta cerimônia acadêmica, incluindo os familiares. Não poderia calar, do mesmo modo, a dívida que tenho com minha esposa, Ângela, e com meus filhos, Eduardo e Sérgio, pelo apoio e carinho com que sempre acolheram minha atividade acadêmica. Mas eu não poderia terminar estes agradecimentos sem expressar uma nota de tristeza e resignada saudade que tomou conta de mim ao ler a contribuição do querido Pe. Henrique Cláudio de Lima Vaz, mestre e amigo, que me dedicou talvez aquele que foi seu último trabalho. Deus o tenha em Sua infinita glória. 